\title{
RELATIONSHIP BETWEEN ADOLESCENT ATHLETES' VALUES AND BEHAVIOR IN SPORT AND PERCEIVED COACH'S CHARACTER DEVELOPMENT COMPETENCY
}

\author{
Tomas Stupuris, Saulius Šukys, Ilona Tilindienė \\ Lithuanian Sports University, Kaunas, Lithuania
}

\begin{abstract}
Research background and hypothesis. This study examined the relations between reported youth athletes' prosocial and antisocial behavior and personal and social factors in sport context and whether these variables accounted for age and sports experience differences in reported behaviors values in sport and perceptions of coach's character development competency.

The aim of the research was to determine age and sports experience differences in manifestation of youth athletes' values in sport, perceived coach's character development competency and behaviors that occur in sport, and to examine interrelations between these variables.

Research methods. The sample included 201 athletes recruited from Kaunas and Alytus sports schools. The participants completed the Youth Sport Value Questionnaire-2 (YSVQ-2 - Lee et al., 2008), the Prosocial and Antisocial Behavior in Sport Scale (PABSS - Kavussanu, Boardley, 2009), and adapted version of the Coaching Efficacy Scale (CES- Feltz et al., 1999).

Research results. The positive correlation between values in sport, perceived coach's character development competency and prosocial behavior of athletes were established. These values also had negative correlations with antisocial behavior whereas status values correlated negatively with prosocial behavior. Coach's character development competency was perceived stronger by younger athletes $(\mathrm{p}<0.05)$. Competence values were more important to these athletes compared to older ones $(\mathrm{p}<0.05)$.

Discussion and conclusions. Research revealed the importance of moral and competence values for adolescent athlete's moral behavior in sport. Perceived character-development effectiveness positively correlated with athletes' prosocial behavior; however, it was unrelated to antisocial behavior. Thus, perceiving the coach as being effective in instilling an attitude of good moral character may lead to an increased frequency of desirable behaviors but does not appear to have any effect on antisocial conduct. It was found that athletes' prosocial acts were more frequent than antisocial ones, however, more experienced athletes displayed more frequent antisocial behavior to the teammates. These findings are consistent with the previous presumption that low frequency of engagement in antisocial behaviors does not necessarily mean that one frequently engages in prosocial action, or vice versa.
\end{abstract}

Keywords: sport, athletes' moral behavior, values in sport, perceptions, coaching effectiveness.

\section{INTRODUCTION}

$\mathrm{S}$ port is a social environment where athletes interact with each other and there they can gain negative sports experience if they seek to win by any means being unfair to other athletes, appealing referees' decisions or taking revenge on an opponent after a rough tackle. Though, at the same time, the sports social context allows them to create the conditions for positive sports experiences, when a teammate is supported after unsuccessful performance, or an opponent is helped when injured (Boardley, Kavussanu, 2009). Despite the durability of sports existence and consistent views about its positive impact on the development of athletes, only recently attention has been paid to the issues 
of moral behavior in sport (Kavusanu, 2006). It is claimed that there is a lack of the empirical evidence in order to prove this fact (Shields, Bredemeier, 2007; Lee et al., 2008; Šukys, 2010).

Behavior in sport is not only a perfect example of an athlete's character, but it can also have positive or negative effect on other participants (Kavussanu, 2008). In this context the prosocial behavior of athletes is most relevant. It should be noted that such behavior has not been studied yet and in the scientific literature it is described as voluntary actions to help another person (Eisenberg, Fabes, 1998; Eisenberg, Müssen, 1989). Examples of this behavior in sport could be offering help to an injured opponent or verbal encouragement to a teammate. Prosocial behavior is possible for various reasons, e. g. such behavior is beneficial to another person (Eisenberg, Müssen, 1989), thus, such forms of behavior are important and expected (Kavussanu, 2005). Aiming at showing that sport can be an effective agent of educating athletes' character, it is necessary to determine how prosocial behavior occurs in sports context and what could lead to such behavior (Kavussanu, 2008).

The most investigated factors that predetermine athletes' behavior are goal orientations and their motives. Over the past decade, research has demonstrated well enough what psychological consequences on athletes' behavior raise from the interpretation of success in sports activities as well as what should be emphasized in order to reduce these behavioral problems (Boardley et al., 2008; Kavussanu et al., 2006). More often paying attention to the prevailing values in sports context, researchers emphasize that their influence on athletes' behavior is still not known enough (Šukys, Jansoniené, 2012; Šukys, 2010; Lee et al., 2008). Values are human priorities based on feelings, beliefs and practices which will guide people through their lives (Vasiliauskas, 2005). Values act as a motivating factor which provides the action with its direction and intensity, serves as standards for the assessment of behavior (Schwartz, 1994). Therefore, if the values influence our decisions in certain situations, then they should determine the behavior in sports' activities.

Much attention has been also paid to the effect of sports social environmental factors on positive and negative behaviors of athletes (Boardley, Kavussanu, 2009). It was found that the motivational climate of the practice session could have both positive and negative effect on athletes' moral behavior variables (Kavussanu,
2006) but the research shows, that this factor can have more significance for athletes' behavior within a team, but not the opponents. On the other hand, educational activity of the coach should fully involve young athletes' personality development aspects (Miškinis, 2011). Coach is said to be the most influential personality in athlete's life (Horn, 2002), he/she is responsible for the development not only of the training climate, but for athlete's character as well. Skilled coaches can influence various aspects of athletes' sports experience, social skills and character qualities; and the coaches are competent to develop athletes' character. Competence in character development is coach's faith in his/ her personal capacity to develop personality and positive attitudes to sport (Feltz et al., 1999). Coaches who have high character development expertise often show a positive example for athletes demonstrating honorable sports behavior and respect for other sports participants. The trainees of these coaches are more motivated, more self-confident, their sports results are higher, they are more in favor of their coach and more likely to act according to the principles of honorable sports behavior and express positive attitudes to sport (Feltz et al., 1999; Kavussanu, 2008).

It is also worthwhile to note that the investigation of athletes' honorable behaviors and the factors influencing them in sports requires valid and reliable research instruments. Although a number of studies have been conducted in this area in Lithuania and abroad during the last decade, some researchers (Kavussanu et al., 2008; Šukys, 2010) argue there is still a lack of research applying reliable and valid research instruments adapted in sports context. Referring to these statements about the athletes' behavioral problems in the context of sport as well as new research instruments presented in the academic research journals (Šukys, 2010), we set our research aim to reveal athlete students' value orientations and behaviors in sports activities and their attitudes towards their coach's competence in character development (depending on their age and experience in sport) and their interrelations.

\section{RESEARCH METHODS}

Subjects. The study sample consisted of 201 selectively chosen 15-19-year-old students from team sports. Their average age was $(\mathrm{M}=17.22$ $\mathrm{SD}=22.1)$. The subjects were divided into groups according to the median students' age: $15-17$ 
$(n=105)$ and $18-19(n=96)$ years. The interviewed students played basketball $(\mathrm{n}=105)$, handball $(n=21)$, football $(n=44)$, ice hockey $(n=16)$ and rugby $(n=15)$. Students were in their selected sports for $(\mathrm{M}=5.78 ; \mathrm{SD}=2.38)$ years on average. Subjects were divided into two groups according to the median of sports experience: those in sports for less than six years $(\mathrm{n}=101)$, and those in sports for six or more years $(n=100)$.

Methods. Questionnaire survey method was used in the study. The questionnaire consisted of social-demographic (gender, age, sports experience) and diagnostic parts. Diagnostic part included a number of scales and questionnaires to collect information on the dependent variables in the study: values in sports activities, expressions of athletes' prosocial and antisocial behaviors in sports, attitude to coach's competence to develop athletes' character.

In clarifying what values are most important for students in sports activities Youth Sport Values Questionnaire (Youth Sport Values QuestionnaireLee et al., 2008) was used. It consisted of thirteen statements, each of which had to be assessed by the students choosing one of seven response options from especially important to me (5) to contrary to what I believe (-1). All thirteen statements formed three groups of values: moral, skill development and status values. Lithuanian version of this scale was adapted in the previous studies (Šukys et al., 2011) using a sample of student athletes.

Aiming at establishing students' behaviors in sports activities, Prosocial and Antisocial Behavior in Sport Scale was applied (The Prosocial and Antisocial Behavior in Sport Scale - Kavussanu et al., 2008), which consisted of 20 behavioral examples. Students had to answer how often during the past year they had to do the following actions which were specified by choosing one of five response options from never (1) to very often (5). It should be noted that there were two behavior factors of prosocial (prosocial behavior with team mates and rivals) and two factors of antisocial behavior (antisocial behavior with team mates and rivals) in this sale. Lithuanian version of this scale was adapted in the previous studies (Šukys et al., 2011) using a sample of student athletes.

Aiming at establishing how student athletes evaluate coaches' character development competency, coaching competency scale of four statements was applied (Coaching Competency Scale - Myers et al., 2006). The respondents rated four statements that began with "How does your coach manage ..." selecting one of the nine response options from completely failing (1) to absolutely being able (9).

Research process. The survey was carried out in Kaunas and Alytus city sports schools in February, March and April of 2012. The cities were chosen for the survey because of a sufficiently large popularity of team sports, rich number of adolescents engaged in sports and the dominance of children teams from these cities in various national championships. Having received the permission of the director and the coach of sports school, the students were explained the objectives of the study and guaranteed anonymity of participation in the research before the practice session, then they were asked to complete questionnaires. The study complied with the ethical and legal research principles.

Statistical analysis. Data processing was carried out using SPSS-17.0 for Windows OS. After the data distribution and descriptive statistics procedures, the average response value and the standard deviation was determined. Aiming at evaluating the structure of the questionnaire, exploratory factor analysis was used applying the essential components and orthogonal varimax rotation methods. The adequacy of the data for factor analysis was tested using Bartlett's test of sphericity. Derived factor (scale) internal consistency was assessed by calculating the internal consistency (Cronbach's alpha) values. In order to determine the connection between the variables the Spearman's rank correlation method was applied. To determine the differences of the means between the groups, Mann and Whitney U test for independent samples was used.

\section{RESEARCH RESULTS}

Analyzing the results of student athletes' values in sports activities, we attempted to identify factors using the mathematical model of the exploratory factor analysis. Factor analysis was applied as a Lithuanian version of the scale was adapted on the basis of a sample of student athletes. It was found that the values of youth sports activities questionnaire results were suitable for the factor analysis $-\mathrm{KMO}=0.86$, Bartlett's test of sphericity value was $p<0.001$. Data of the derived factor eigenvalues and explanatory dispersion are given in Table 1. It should be noted that all of the statements 
Table 1. Items and factor loading for Youth Sport Values Questionnaire (YSVQ) $(\mathbf{n}=\mathbf{2 0 1})$

\begin{tabular}{|c|c|c|c|}
\hline \multirow{2}{*}{ Behaviors Factors } & \multicolumn{3}{|c|}{ Factor loads } \\
\hline & COM & MRL & STT \\
\hline 6. I strive to become a good athlete & 0.89 & & \\
\hline 7. I seek to reveal my physical activity skills & 0.86 & & \\
\hline 8. For me it is important to set a goal that I want to achieve during physical activity & 0.82 & & \\
\hline 9. For me it is important to improve my sporting prowess & 0.79 & & \\
\hline 5. It is important for me to be honest in sport & & 0.83 & \\
\hline 4. While playing sports - always try to follow the rules & & 0.79 & \\
\hline 3. I strive to help others when they need it & & 0.77 & \\
\hline 2. It is important to compete in sports honestly & & 0.77 & \\
\hline 1. During physical activity, I agree to do what I am told & & 0.65 & \\
\hline 13. I find it important to look good & & & 0.89 \\
\hline 11. I strive to be a team leader & & & 0.84 \\
\hline 12. For me it is important to win or defeat & & & 0.78 \\
\hline 10. I strive to be better than the other & & & 0.75 \\
\hline Explained dispersion's cumulative \% & 25.55 & 51.06 & 73.16 \\
\hline
\end{tabular}

Note. COM - competence values; MRL - moral values; STT - status values.

composed three factors explaining 73.16 percent of the total dispersion. The internal consistency of all three ranges of values was good ( 0.70 to 0.85 ).

It was found that data of prosocial and antisocial behaviors in sport scale is suitable for factor analysis for averaged $\mathrm{KMO}=0.78$, Bartlett's test of sphericity, $\mathrm{p}<0.001$. Principal components analysis and orthogonal Varimax rotation is used. Data on the derived factors' eigenvalues and explained dispersion are in Table 2. It should be noted that all of the statements make four factors explaining 69.18 percent of the total dispersion. All scales' internal consistency score is appropriate (from 0.79 to 0.85 ).

Descriptive statistics and correlations for study variables are displayed in Table 3. According to the survey most students doing sports emphasized capacity-building values; less relevant to them were moral values and status values were the least important. Analyzing the data of athletes' behavior in sports activities it was found that prosocial behavior with team members was the most typical, and prosocial behavior with rivals was less typical of them. The results showed that antisocial behavior both with teammates and rivals was not very common, i. e. students rarely acted in this way. Interviewed students valued their coach's competence in developing the athlete's character well. Analysis of the data demonstrated a positive correlation between moral and capacity-building values, as well as the capacity-building and status values. The corresponding correlations between the prosocial behavior with the teammates and opponents, antisocial behavior with the teammates and rivals were determined, as well as a negative correlation between the prosocial behavior with the teammates and antisocial behavior with the rivals. Also the relationship between moral values and prosocial behavior were revealed as well as negative relationships with the antisocial behavior. Capacity-building values were positively related to prosocial behavior and negatively linked with antisocial behavior. These included a negative correlation between the status values and prosocial behavior with the opponents. The study revealed a correlation between the student athletes' expressed opinion about the coach's competence to develop the character and their prosocial behavior, as well as moral and capacity-building values. 
Table 2. Factors indicated by adolescents' prosocial and antisocial behavior in sport and the dispersion explaining them $(\mathbf{n}=\mathbf{2 0 1})$

\begin{tabular}{|c|c|c|c|c|}
\hline \multirow{2}{*}{ Behavior factors } & \multicolumn{4}{|c|}{ Factor loads } \\
\hline & ABWR & ABWP & PBWP & PBWR \\
\hline 16. Intentionally annoyed the opponent trying their patience & 0.79 & & & \\
\hline 17. Avenged an opponent for his brutal foul in the same way & 0.78 & & & \\
\hline 14. Provoked an opponent to perform prohibited actions & 0.77 & & & \\
\hline 19. Threatened physically in order to intimidate an opponent & 0.74 & & & \\
\hline 18. Intentionally violated the rules of sporting contest & 0.71 & & & \\
\hline 15. Intentionally fouled against an opponent & 0.67 & & & \\
\hline 13. Tried to injure an opponent & 0.66 & & & \\
\hline 20. Criticized a rival & 0.61 & & & \\
\hline 12. Showed dissatisfaction with poor game of a team member/members & & 0.84 & & \\
\hline 10. Argued with a team member/members & & 0.83 & & \\
\hline 11. Criticized a team member/members & & 0.79 & & \\
\hline 9. Cursed a team member/members & & 0.78 & & \\
\hline 8. Abused a team member/members & & 0.72 & & \\
\hline 2. Congratulated a team member/members for a good game & & & 0.89 & \\
\hline 1. Encouraged, cheered on a team member/members & & & 0.86 & \\
\hline 3. Responded positively about a team member/members & & & 0.83 & \\
\hline 4. Advised a team member/members & & & 0.82 & \\
\hline 5. Helped the injured opponent & & & & 0.87 \\
\hline 6. Requested to stop the sports contest after an injury of an opponent & & & & 0.87 \\
\hline 7. Helped the injured opponent & & & & 0.72 \\
\hline Explained dispersion's cumulative \% & 22.9 & 41.18 & 57.19 & 69.18 \\
\hline
\end{tabular}

Note. ABWR - antisocial behavior with the rivals; ABWP - antisocial behavior with the team; PBWP - prosocial behavior with the team; PBWR - prosocial behavior with the rivals.

Table 3. Correlations, scale compatibility, and the main results of the study. Cronbach's alpha are reported on the diagonal

\begin{tabular}{|l|c|c|c|c|c|c|c|c|}
\hline \multicolumn{1}{|c|}{ Variables } & $\mathbf{1}$ & $\mathbf{2}$ & $\mathbf{3}$ & $\mathbf{4}$ & $\mathbf{5}$ & $\mathbf{6}$ & $\mathbf{7}$ & $\mathbf{8}$ \\
\hline 1. MRL & $(0.86)$ & & & & & & & \\
\hline 2. COM & $0.48^{* *}$ & $(0.93)$ & & & & & & \\
\hline 3. STT & 0,02 & $0.16^{*}$ & $(0.85)$ & & & & & \\
\hline 4. CC & $0.23^{*}$ & $0.17^{*}$ & -0.11 & $(0.96)$ & & & & \\
\hline 5. PBWP & $0.29^{* *}$ & $0.37^{* *}$ & -0.03 & $0.34^{* *}$ & $(1.89)$ & & & \\
\hline 6. PBWR & $0.22^{* *}$ & $0.15^{*}$ & $-0.14^{*}$ & $0.14^{*}$ & $0.45^{* *}$ & $(1.83)$ & & \\
\hline 7. ABWP & $-0.24^{* *}$ & $-0.14^{* *}$ & -0.08 & -0.05 & -0.08 & 0.12 & $(0.89)$ & \\
\hline 8. ABWR & $-0.38^{* *}$ & $-0.19^{* *}$ & 0.10 & -0.11 & $-0.16^{* *}$ & -0.002 & $0.58^{* *}$ & $(0.89)$ \\
\hline The average score & 3.62 & 3.97 & 2.77 & 6.96 & 4.10 & 2.90 & 2.37 & 2.22 \\
\hline
\end{tabular}

Note. COM - Competence values; MRL - moral values; STT - status values; CC - Coatching competency; ABWR - antisocial behavior with the rivals; ABWP - antisocial behavior with the peers; PBWP - prosocial behavior with the peers; PBWR - prosocial behavior with the rivals. * - statistically significant difference $(\mathrm{p}<0.05) ; * *$ - statistically significant difference $(\mathrm{p}<0.01)$. 
Table 4. Athletes' values, prosocia and antisocial behaviors, and the evaluation of coach's competence to develop character in the aspect of their age and sports experience

Note. COM - Competence values; MRL - moral values; STT - status values; CC - Coaching competency; ABWR - antisocial behavior with the rivals; ABWP - antisocial behavior with the peers; PBWP - prosocial behavior with the peers; PBWR - prosocial behavior with the rivals. * - statistically significant difference $(\mathrm{p}<0.05)$ ** - statistically significant difference $(\mathrm{p}<0.01)$.

\begin{tabular}{|c|c|c|c|c|c|c|}
\hline & \multicolumn{2}{|c|}{ Age } & \multirow[b]{2}{*}{$\mathbf{U}$} & \multicolumn{2}{|c|}{ Sports experience } & \multirow[b]{2}{*}{$\mathbf{U}$} \\
\hline & $\begin{array}{l}\text { Till } 17 \\
\text { years }\end{array}$ & $\begin{array}{l}18-19 \\
\text { years }\end{array}$ & & Till 6 years & 6 and more & \\
\hline 1. MRL & 3.71 & 3.52 & & 3.76 & 3.47 & 4347.0 \\
\hline 2. COM & 4.25 & $3.66^{* *}$ & $3715.5 * *$ & 3.95 & 3.98 & \\
\hline 3. STT & 2.87 & 2.66 & & 2.66 & 2.88 & \\
\hline 4. $\mathrm{CC}$ & 7.03 & 6.89 & $4191.5^{*}$ & 7.05 & 6.88 & \\
\hline 5. PBWP & 4.03 & 4.18 & 4328.5 & 4.04 & 4.17 & \\
\hline 6. PBWR & 2.80 & 3.01 & & 2.87 & 2.93 & \\
\hline 7. ABWP & 2.39 & 2.34 & & 2.25 & 2.48 & $4099.5^{*}$ \\
\hline 8. ABWR & 2.27 & 2.18 & & 2.13 & 2.32 & \\
\hline
\end{tabular}

Differences in the evaluations of value orientations, behavior in sport and coach's competence are determined in the aspects of age and experience (Table 4). The average response values indicate that for younger athletes capacity building values are more important than for the older ones $(U=3715.5 ; p<0.01)$; younger athletes value their coach's competence to develop character better than their senior counterparts $(U=4191.5$; $\mathrm{p}<0,05)$. However, in the senior group we found a better prosocial behavior tendency with their teammates $(U=4328.5 ; p=0.08)$. The analysis of the remaining variables among age groups did not reveal significant differences. When analyzing the data in the aspect of sports experience we found that athletes who were engaged in their sports activities longer demonstrated antisocial behavior with their teammates more frequently $(\mathrm{U}=4099.5$; $\mathrm{p}<0.05$ ), students with lower sports experience emphasized moral values $(U=4347.0 ; p=0.09)$.

\section{DISCUSSION}

Using the mathematical model of an exploratory factor analysis we established three groups of values, thirteen statements were divided into three groups describing moral, capacity building and status values. We also identified four forms of behavior and statements representing them, and the identified correlation between moral and capacity building, capacity building and status values groups matched the trend links established in earlier studies (Šukys, 2010; Šukys, Jansonienè, 2012). Also the communication tendencies between the two positive and two negative behaviors match with these studies, but, unlike the authors of these studies, we found a weak negative relationship between pro-social behavior with the teammates and antisocial behavior with the rivals. In assessing the reliability of the questionnaire, the scales showed a good internal consistency scores.

The analysis of our research results on the athletes' values, behaviors in sport and the evaluation of the coach's competence in the development of character showed that the moral and competence values in sport positively correlated with the prosocial behavior in a team and with competitors, however, they negatively correlated with the antisocial behavior in a team and the opponents. Moral group of values had the strongest link with the four forms of athletes' behavior in sport; the strongest was their negative link with antisocial behavior and with the rivals. The relationship of moral values confirmed previous findings (Šukys, 2010). The latter interface can be explained by the fact that the athletes' fairness and the emphasis on the compliance to the rules are the expression of moral values, so athletes should demonstrate less disgraceful behavior when competing (Lee et al., 2008). The group of capacity building values had weaker links than moral values, but the interface of prosocial behavior with the teammates was the strongest. The emphasis of sportsmanship can be seen as an expression of the capacity building values (Lee et al., 2008). In team sports, success in personal sports results can vary depending on the relationships in a team (Meidus, 2007), probably because these values have the maximum interface with prosocial behavior with teammates as the encouragement and support of the teammates may 
lead to better team as well as individual sports results (Meidus, 2007). The strength of this interface is also consistent with the previous research findings (Šukys, 2010). Group of status values had a weak negative link with the prosocial behavior with the opponents. Scientists explain this link by the fact that the emphasis of victory could lead to less friendly behavior (Lee et al., 2008). Evaluation of coach's competence in developing character is positively associated with prosocial behavior forms and moral values as well as and capacity building values. However, a negative relationship with the status values and forms of antisocial behavior has not been identified. These research findings are adequate to the results of the research carried out earlier (Boardley et al., 2008). We suggest that competent and targeted coach's work, developing athlete's positive attitudes towards honorable sport behavior and respect for others, can bring positive results in the desirable athletes' behavior but it is not significant to the negative behavior of people in sport. According to scientists, such research method of the coach's competence explains the fact that there is no connection with the antisocial variables. The statements of these scales talk about the positive aspects of morality, such as a positive attitude towards the noble sport contest and behavior. Meanwhile, statements in the antisocial behavior scale describe actions that cause injustice to other sports participants and include the negative aspects of morality. According to I. D. Boardley (2008), less recurrent athletes' antisocial behavior shows the functioning of higher morality in sports context.

The study also sought to determine the value orientations ofyouth athletes, behavioral expressions in sports activities and the attitude towards coach's competency of character development in the aspect of age and sports experience. According to the data of our study, the capacity-building values are more important for the group of younger athletes. These results are contrary to the findings produced in previous studies (Lee et al., 2000; MacLean, Hamm, 2008) which stated that for the younger athletes moral values are more important than their capacity, scientists suggest that younger athletes lack sports skills and a sense of competence, thus they are not very much involved in sports, that is why their personal development of sportsmanship may still not be as relevant as for their counterparts in higher levels of sportsmanship. Although our study found the opposite, attention is drawn to the fact that in the younger group there could be quite enough experienced athletes attending practice sessions for six or more years. This controversial question arising from our study can be answered by our research data of sports experience indicating that less experienced athletes tended to emphasize moral values. It should be noted that other researchers (Lee et al., 2000; MacLean, Hamm, 2008) have found that not the age of athletes but the successful practice in sport leading to ever growing involvement in sport activities have more significant impact on sports value orientation.

In the research of sports behavior expression, respondents said that during the past year in sports they acted prosocially more often than antisocially; senior athletes demonstrated more friendly behavior with the teammates than the younger ones. Amicable tendency of such behavior can be explained (Meidus, 2007) by several assumptions that during intensive communication in a team sport, players form their emotional relationships and group interaction skills. It may be assumed that older study participants have better developed their relationships than the younger ones, so they are friendlier with their teammates. Although the survey participants said that over the past year they behaved antisocially less frequently, the study results suggest that more experienced athletes behave antisocially with their teammates more often. The research shows (Kavussanu et al., 2008) that when sport experience is increasing athletes take a more positive look on certain forms of antisocial behavior; that is why antisocial behavior may become more frequent. It was also found (Šukys et al., 2011) that during highly psychologically stressful competition athletes' relationships can become more aggressive. Thus, the research data of prosocial and antisocial behavior confirm the results of the previous studies and the assumptions raised by the scientists that prosocial and antisocial behavior reflects two independent dimensions of morality, mean that not necessarily antisocial behavior of prosocially acting athletes should be less common, and vice versa (Kavussanu, 2006).

According to the survey, coach's ability to develop the positive attitudes towards the honorable sports behavior is valued by younger athletes more favorably than by the older ones, but in the aspect of sports experience no significant difference was found. Young athletes' approach to coach's competencies can be explained by similar assumptions concerning age and sports experience, but with increasing experience in sport athletes can 
become more critical to the coach (Kavussanu et al., 2008). Although according to our study we found a more favorable evaluation of younger athletes, which could possibly mean that older athletes value their coach more critically because of their athletic experience, but the study data did not confirm this assumption on the basis of athletic experience. The results of our study did not confirm the assumptions made in the research (Kavussanu et al., 2008) due to the fact that these authors included children of various ages and sports experience.

\section{CONCLUSION AND PERSPECTIVES}

According to our study, moral values and capacity building values are of the highest importance to athletes' behavior. A positive relation was established between the coach's competence and athletes' positive behavior, moral, capacity building values, which shows that competent and targeted coach's work in developing positive attitudes towards the honorable athlete's sports behavior, respect for others, can bring positive results for the desired athletes' behavior, however, it does not affect negative athletes' behavior.

For younger athletes, capacity building values are more important than for the older ones, younger athletes also more positively value coach's ability to develop virtuous character of an athlete as well as positive attitudes towards sport. It has been found that adolescent athletes behave prosocially more frequently than antisocially, but the latter behavior is more specific for more experienced athletes. The results confirm the fact that prosocially acting athletes' antisocial behavior may not necessarily be less common, so in order to know the behavior in the sports context better, in the future pro-social behavior should be examined together with the antisocial behavior.

\section{REFERENCES}

Boardley, I. D., Kavussanu, M., Ring, C. (2008). Athletes' evaluations of coaching effectiveness and psychosocial outcomes in rugby union. The Sport Psychologist, 22, 269-287.

Boardley, I. D., Kavussanu, M. (2009). The influence of social variables and moral disengagement on prosocial and antisocial behaviours in field hockey and netball. Journal of Sports Sciences, 27 (8), 843-854.

Eisenberg, N., Fabes, R. A. (1998). Prosocial development. In N. Eisenberg (Ed.), Handbook of Child Psychology, Vol 3: Social, emotional, and personality development (pp. 701-778). NY: Wiley.

Eisenberg, N., Müssen, P. H. (1989). The Roots of Prosocial Behaviour in Children. Cambrige: Cambrige University Press.

Feltz, D. L., Chase, M. A., Moritz, S. E., Sullivan, P. J. (1999). A conceptual model of coaching efficacy: Preliminary investigation and instrument development. Journal of Educational Psychology, 91, 765-776.

Horn, T. S. (2002). Coaching effectiveness in the sport domain. In T. S. Horn (Ed.), Advances in Sport Psychology (pp. 309-354). Champaign, IL: Human Kinetics.

Kavussanu, M., Boardley, I. D., Jutkiewicz, N., Vincent, S., Ring, C. (2008). Coaching efficacy and coaching effectiveness: Examining their predictors and comparing coaches' and athletes' reports. The Sport Psychologist, 22, 383-404.

Kavussanu, M. (2008). Moral behavior in sport: A critical review of the literature. International Review of Sport and Exercise Psychology, 1 (2), 124-138.
Kavussanu, M. (2006). Motivational predictors of prosocial and antisocial behaviour in football. Journal of Sports Sciences, 24 (6), 575-588.

Kavussanu, M., Seal, A., Phillips, D. (2006). Observed prosocial and antisocial behaviors in male soccer teams: Age differences across adolescence and the role of motivational variables. Journal of Applied Sport Psychology, 18 (4), 326-344.

Lee, M. J., Whitehead, J., Balchin, N. (2000). The measurement of values in youth sport: Development of the Youth Sport Values Questionnaire. Journal of Sport and Exercise Psychology, 22, 307-326.

Lee, M. J., Whitehead, J., Ntoumanis, N., Hatzigeorgiadis, A. (2008). Relationships among values, achievement orientations, and attitudes in youth sport. Journal of Sport and Exercise Psychology, 30 (5), 588-610.

MacLean, J., Hamm, S. (2008). Values and sport participation: Comparing participant groups, age, and gender. Journal of Sport Behavior, 31 (4), 352-360.

Meidus, L. (2007). Pedagoginis sporto poveikis sportininkų bendravimui ir sąveikai. Sporto mokslas, 3 (49), 21-24.

Miškinis, K. (2011). Daugybos lentelè treneriui. Treneris, 3, 3-8.

Myers, N. D., Feltz, D. L., Maier, K. S., Wolfe, E. W., Reckase, M. D. (2006). Athletes'evaluations of their head coach's coaching competency. Research Quarterly for Exercise and Sport, 77, 111-121.

Šukys, S., Jansonienė, A. J. (2012). Relationship between athletes values and moral disengagement in sport and differences across gender level and years of 
involvement. Ugdymas. Kūno kultūra. Sportas, 1 (84), 55-61.

Šukys, S. (2010). Prosocialaus ir antisocialaus elgesio skalès bei jaunimo vertybiu sportinèje veikloje klausimyno adaptavimas lietuviams. Ugdymas. Küno kultūra. Sportas, 3 (78), 97-104.
Šukys, S., Zakrasienè-Stanevičiūtè, V., Nickus, E., Šukienè, E. (2011). Manifestation of prosocial and antisocial behavior in a basketball match. Ugdymas. Küno kultūra. Sportas, 4 (83), 69-76.

Vasiliauskas, R. (2005). Vertybių ugdymo teoriniai ir praktiniai aspektai. Acta Paedagogica Vilnensia, 14, 45-54.

\title{
SPORTUOJANČIŲ PAAUGLIŲ VERTYBINIŲ ORIENTACIJŲ, SPORTINIO ELGESIO IR TRENERIO KOMPETENCIJOS UGDYTI SPORTININKŲ CHARAKTERI VERTINIMO SĄSAJOS
}

\author{
Tomas Stupuris, Saulius Šukys, Ilona Tilindienè \\ Lietuvos sporto universitetas, Kaunas, Lietuva
}

\section{SANTRAUKA}

Tyrimo pagrindimas ir hipotezė. Straipsnyje analizuojama sportuojančiu paaugliu prosocialaus bei asocialaus elgesio sąsajos su asmeniniais, socialiniais veiksniais sportuojant ir kaip šie kintamieji priklauso nuo amžiaus ir sportinès patirties, vertybinių orientacijų bei trenerio kompetencijos ugdyti sportininko charakteri vertinimo.

Tikslas - atskleisti sportuojančių moksleivių vertybinių orientacijų ir elgesio sportinèje veikloje bei trenerio kompetencijos ugdyti sportininko charakterị vertinimo sąsajas atsižvelgiant ị amžiu ir sportinę patirti.

Metodai. Tiriamają imtị sudare 201 tikslines komandines sporto šakas kultivuojantis moksleivis iš Kauno ir Alytaus sporto mokyklų. Aiškinantis, kokios vertybès sportuojantiems moksleiviams yra svarbiausios sportinëje veikloje, taikytas Jaunimo vertybių sportinèje veikloje klausimynas (Youth Sport Values Questionnaire - Lee et al., 2008). Aiškinantis sportuojančiu moksleiviu elgesị sportineje veikloje taikyta Prosocialaus ir antisocialaus elgesio sportineje veikloje skalè (The Prosocial and Antisocial Behavior in Sport Scale - Kavussanu, Boardley, 2009) ir adaptuota Trenerio charakterio ugdymo kompetencijos skalè (CES - Feltz et al., 1999).

Rezultatai. Nustatyta teigiama koreliacija tarp sporto vertybių, trenerio kompetencijos ugdyti sportininko charakteri ir prosocialaus sportininkų elgesio. Šie kintamieji neigiamai koreliuoja su asocialiu elgesiu, o statuso vertybès - su prosocialiu elgesiu. Trenerio kompetenciją ugdyti charakterị labiau suvokia jaunesni sportininkai $(\mathrm{p}<0,05)$. Taip pat kompetencijos vertybès buvo svarbesnès šiems sportininkams, lyginant su vyresniaisiais $(\mathrm{p}<0,05)$. Mann-Whitney $U$ testas parodè skirtumą tarp nevienodą sportinę patirtį turinčių sportininkų asocialaus elgesio su komandos draugais - dažniau taip elgiasi didesnę patirtį turintys sportininkai $(\mathrm{p}<0,05)$.

Aptarimas ir išvados. Tyrimo duomenimis, moralinių ir gebejimų ugdymo vertybių grupès turi didžiausią reikšmę sportininko elgesiui. Teigiamas trenerio kompetencijos vertinimo ryšys su pozityviu sportininkų elgesiu, moralinèmis ir gebėjimų ugdymo vertybėmis rodo, kad kompetentingas bei kryptingas trenerio darbas ugdant sportininko garbingo sportinio elgesio nuostatas ir pagarbą kitiems gali išugdyti pageidautiną sportininko elgesị ir neturi reikšmès neigiamam sportuojančiujų elgesiui.

Jaunesniems sportininkams gebèjimų ugdymo vertybės svarbesnès nei vyresniems, jaunesnieji palankiau vertina trenerio gebėjimą ugdyti dorą sportininko charakterị bei teigiamą požiūrị i sportą. Nustatytas sportuojančių paaugliu prosocialus elgesys dažnesnis nei antisocialus, tačiau pastarasis būdingesnis labiau patyrusiems sportininkams. Tyrimo rezultatai patvirtina faktą, kad prosocialiai besielgiančiu sportininkų antisocialus elgesys nebūtinai turi būti retesnis. Taigi norint geriau pažinti sportini elgesi ateityje prosocialus elgesys turètų būti tiriamas kartu su antisocialiu.

Raktažodžiai: sportas, moralus sportininkų elgesys, sporto vertybès, treneriu teigiamos veiklos suvokimas. 